Review

\title{
Ecosystem Services of Kettle Holes in Agricultural Landscapes
}

\author{
Filip Vasić ${ }^{1}(\mathbb{D})$, Carsten Paul ${ }^{1, *}$, Veronika Strauss ${ }^{1}$ (D) and Katharina Helming ${ }^{1,2}$ (D) \\ 1 Leibniz Centre for Agricultural Landscape Research ZALF, Eberswalder Straße 84, 15374 Müncheberg, \\ Germany; filipvasic24@yahoo.com (F.V.); veronika.strauss@zalf.de (V.S.); helming@zalf.de (K.H.) \\ 2 Faculty of Landscape Management and Nature Conservation, Eberswalde University for Sustainable \\ Development (HNEE), Schicklerstr. 5, 16225 Eberswalde, Germany \\ * Correspondence: carsten.paul@zalf.de
}

Received: 19 June 2020; Accepted: 26 August 2020; Published: 4 September 2020

\begin{abstract}
Kettle holes are small water bodies of glacial origin which mostly occur in agricultural landscapes. They provide numerous ecosystem services (ES), but their supply may be negatively affected by agricultural management. We conducted a literature review to identify which ES are supplied by kettle holes and to analyze feedbacks with agricultural management. Taking Germany as a test case, we also analyzed how kettle holes are addressed in policy documents and for which ES they are regulated. This was done to identify the societal value officially associated with kettle holes. The literature review found eight ES attributed to kettle holes, of which hydrological cycle and flood control, chemical condition of freshwaters, nursery populations and habitats and biotic remediation of wastes were addressed most often. In contrast, only the provision of habitat service was addressed in German policy documents related to kettle holes. We identified types of agricultural management that negatively affected the supply of ES by kettle holes, in particular artificial drainage, high levels of pesticide and fertilizer application, and management where tillage and erosion result in elevated sediment inputs. Additionally, climate change may lead to an increased drying up of kettle holes. Based on our finding, we conclude that the intensity of agricultural management around kettle holes threatens the supply of all ES while only the service of providing habitats for biodiversity is addressed in German policy regulations. Further regulation is required to induce agricultural management change towards a conservation of all ES supplied by kettle holes.
\end{abstract}

Keywords: kettle hole; small water bodies; wetland; ecosystem service; CICES; agricultural management; sustainability; policy; climate change

\section{Introduction}

Agricultural landscapes provide multiple ecosystem services (ES) through interacting land uses and geobiophysical settings. These services are defined as the contributions of ecosystem structure and function (in combination with other inputs) to human well-being [1]. Sustainable agricultural management needs to account for site-specific characteristics, including topographic factors and coexisting biotopes. In this regard, a particular challenge to sustainable management arises where fields include kettle holes. Kettle holes are pond-like, depressional wetlands in young moraine landscapes. The term "kettle holes" is preferably used in Europe [2], whereas "potholes" is a synonym used in North America [3]. Kettle holes evolved from topographic depressions formed by delayed melting of remnant ice blocks during the ice retreat after the Pleistocene $~ 10,000-12,000$ years ago $[4,5]$. Older glaciations created similar depressions, but most were lost as a result of bank erosion and sedimentation. Kettle holes typically range in size from 0.01 to 3 ha. Most undergo severe wet-dry cycles and some have ephemeral water bodies [6]. 
Due to their origin in the latest glaciation, kettle holes are mainly found in the northern part of the northern hemisphere. Kettle holes have been described in: Canada [7], USA [8,9], Iceland [10], England [11], Wales [12], Scotland [13], Norway [14], Sweden [15], Finland [16], Denmark [17], Germany [4], Poland [18], Lithuania [19], Estonia [20], Austria [21], Italy [22], Croatia [23] and Russia [24], while in the southern hemisphere they appear in New Zealand [25].

Kettle holes fulfill important hydrological and ecological functions [26]. Their storage capacity influences a landscape's water retention function and the moisture they provide through evapotranspiration affects local microclimate [27]. They serve as a refuge for endangered species and comprise habitats that promote biodiversity (e.g., [28,29]). Due to their small size and the usually high number of kettle holes in a region, they offer interesting opportunities for ecological research and modeling. In North America, kettle holes represent one of the largest and most hydrologically diverse populations of inland wetlands [30]. Additionally, kettle holes are increasingly recognized as hotspots of carbon (C) turnover [31-33].

Kettle holes are mostly situated in agricultural landscapes. They are often affected by agricultural management and in turn affect the fields surrounding them. The presence of kettle holes in a field may cause conflicts between nature conservation and farmers' economic interests [6]. Intensive agricultural management may cause structural degradation in kettle holes, eutrophication, pollution by plant-protection products, or direct habitat destruction $[4,34,35]$. This may also impair the ecosystem functions and services supplied by kettle holes $[5,36,37]$. Furthermore, due to soil erosion, many kettle holes are increasingly filled with sediment originating from adjacent fields [38]. This threat is exacerbated by climate change which in many locations increases the probability of high intensity rainfall events and thereby the extent of soil erosion. The projected rise in global mean temperatures [39,40] until the end of the century is also likely to contribute to increased rates of evapotranspiration in many regions, resulting in an increasing rate of kettle holes permanently drying up. Both agricultural management and climate change may impair the ecosystem services supplied by kettle holes [5,36,37].

Beyond the perspective of natural sciences, it is also useful to assess the importance that society attributes to kettle holes in agricultural landscapes. This can be done by analyzing the legal frameworks regulating the protection of kettle holes and deriving the reasons given for this protection. For such an analysis, the German federal state of Brandenburg provides an excellent case study. In Germany, the total number of kettle holes is estimated at 150,000-300,000 [6,41]. They only occur in the northeastern part of the country in the three federal states: Brandenburg [6], Mecklenburg-Vorpommern [42] and Schleswig-Holstein $[43,44]$. In some regions of these states, kettle holes cover up to $5 \%$ of the arable land [6]. Management of the agricultural land surrounding kettle holes is regulated at different policy levels, ranging from European legislations pertaining to the Common Agricultural Policy down to regulations at federal state and district levels.

To assess the sustainability of agricultural management options in the areas surrounding kettle holes, it is necessary to consider the ecosystem services supplied by kettle holes and the effects that agricultural management has on them. This is similar to an earlier study by Brinson and Eckles who describe ecosystem services supplied by wetlands in agricultural areas of the United States, as well as how agricultural management and implemented conservation practices affect this supply [45]. While many other studies have analyzed effects from a limited number of specific agricultural management practices on selected ES, no paper has yet provided an overview of all ES supplied by kettle holes and assessed the full range of management practices affecting them. This paper contributes to closing this gap through the following objectives:

- Assess the state of knowledge about ES supplied by kettle holes in agricultural landscapes by conducting a review of scientific literature;

- Assess which ES supplied by kettle holes are perceived by society as important and worth protecting by reviewing national (European) to local (German-regional) policy documents as an exemplary test case; 
- Assess the state of knowledge about the interactions between ES supplied by kettle holes and agricultural management on adjacent fields by conducting a review of scientific literature.

\section{Methodology}

\subsection{Kettle Hole Terminology}

Kettle holes are small depressions formed by the melting of remnant ice blocks that are permanently or periodically filled with water. In the USA and Canada, the term pothole is used synonymously. The distinction between kettle holes and larger kettle lakes is often ambiguous and internationally different size definitions are applied. In Germany, kettle holes (Sölle; Toteislöcher) are by definition smaller than 1 ha [6], in New Zealand they are considered to be typically smaller than 4 ha [25]. For the USA and Canada, the distinction between kettle hole and kettle lake is less strict, with some authors reporting typical sizes as smaller than 1 ha [30], up to several hectares [46] or typically smaller than 15 ha [47]. In this manuscript, we did not distinguish between kettle holes of different sizes, as most studies from the USA and Canada did not provide the information necessary to do so.

\subsection{Literature Review}

We reviewed scientific publications that addressed kettle holes or potholes in agricultural areas. A keyword-based search in Web of Science (Core Collection) and Scopus was conducted between March and October 2019. The terms ("kettle hole") OR ("pothole" AND "agric"*) were used to search in titles, abstracts, and keywords. The term "agric*" was added to the search term "pothole" because it is far less specific than the term kettle hole and may also refer to items such as damages in road surfaces. Papers in English or German language were considered; publication date was not used as a selection criterion. Abstracts of all identified papers were reviewed. Articles were excluded if they did not address kettle holes/potholes in agricultural landscapes and at least one of the following topics:

- $\quad$ ES supplied by or influenced by kettle holes;

- Agricultural or climate change related threats to kettle holes;

- Policies and conservation programs aimed at agricultural management in the vicinity of kettle holes that are relevant for our German test case.

A full text analysis was conducted for the remaining publications. All information pertaining to the topics was extracted, including the location of the kettle holes addressed by the respective articles.

For practical reasons, we focused on the potential supply of ecosystem services without analyzing the local demand. For example, where kettle holes provide habitats for amphibian species, we did not distinguish between locations where this service was considered more or less important. This is in line with the majority of studies on ecosystem services. Ecosystem services supplied by kettle holes were recorded using the Common International Classification of Ecosystem Services (CICES) version 5.1 [48]. This was done in order to achieve standardization and facilitate comparisons. The CICES classification was codeveloped by the European Environment Agency. It classifies ecosystem services along 83 service classes organized into the three sections: provisioning services, regulation and maintenance services, and cultural services. The CICES typology of ES is the most detailed classification with a linguistic taxonomy that follows a strict nested hierarchical structure and is widely accepted in Europe and beyond [49]. Compared to other international ES typologies, CICES is more universal, i.e., less specific with regard to particular environments or beneficiaries [50]. We attributed services described in the identified publications to the best matching CICES classes. To aid intuitive understanding, we use simplified names for the CICES classes while also listing the official class code to allow for a clear identification. 


\subsection{Review of Policy Documents}

An analysis of policy documents regulating the protection of kettle holes in the German federal state of Brandenburg was performed from October to December 2019. We analyzed policy documents from the European level down to the federal state level and district levels. Documents were considered if they pertained to the management of water bodies, habitats or the use of fertilizers and pesticides. Table 1 provides an overview of the policy documents examined in our study.

Table 1. Policy documents analyzed in our study. Documents were screened for regulations affecting the protection of kettle holes or the management of surrounding agricultural areas. Ecosystem services (ES) listed as reasons for protecting kettle holes were recorded.

\begin{tabular}{ccc}
\hline Regulation & Policy Level & Reference \\
\hline European Water Framework Directive & Europe & {$[51]$} \\
European Habitats Directive & Europe & {$[52]$} \\
European Nitrates Directive & Europe & {$[53]$} \\
European Directive on Sustainable Pesticide Use & Europe & {$[54]$} \\
Common Agricultural Policy & Europe & {$[55]$} \\
Guropean Regulation on Financing, Management and Monitoring of the & Europe & {$[56]$} \\
German Water Resources Act & Germany & {$[57]$} \\
Federal Nature Conservation Act of Germany & Germany & {$[58]$} \\
German Environmental Damage Act & Germany & {$[59]$} \\
German Fertilizer Ordinance & Germany & {$[60]$} \\
German Fertilizer Act & Germany & {$[61]$} \\
German Plant Protection Act & Germany & {$[62]$} \\
Agricultural Payments Obligations Law & Germany & {$[63]$} \\
Agricultural Payments Obligations Regulation & Germany & {$[64]$} \\
Water Act of Brandenburg & Germany & {$[65]$} \\
\hline Corman Plant Protection Implementing Regulation & Brandenburg & {$[66]$} \\
Biotope Protection Regulation of Brandenburg & Brandenburg & {$[67]$} \\
Nature Conservation Act of Brandenburg (expired) & Brandenburg & {$[68]$} \\
Conservation Target Regulations & Brandenburg & {$[69]$} \\
Organic & Brandenburg & {$[70]$} \\
\hline Act of Brandenburg implementing the Federal Nature & Brandenburg & {$[71]$} \\
\hline binding landscape plans for the districts of Brandenburg & & \\
\hline
\end{tabular}

Using a full text search, we screened all texts for the keywords "kettle hole", "water body", "small water body" and used additional keywords such as "bank", "riparian strip", "biotope", "connect", and "exchange" where applicable. In German texts, the German equivalent of the keywords was used. Where texts were considered relevant, ES listed as reasons for protecting kettle holes were recorded.

\section{Results and Discussion}

\subsection{Overview of Literature on Kettle Holes in Agricultural Landscapes}

The database search for "kettle hole" found 169 articles, of which 36 were considered relevant. Twenty-nine of these referred to kettle holes in Germany, six to kettle holes in Poland and one to kettle holes in New Zealand. The search for "pothole agric" found 233 articles, of which 82 were considered relevant, all of them referring to kettle holes (potholes) in the USA and Canada. USA and Canada are addressed together in this manuscript because most of the identified articles refer to the Prairie Pothole Region which is a part of both countries.

We identified a significant rise in the number of relevant publications over time. Dividing the period between the first identified publication (1993) and the last identified publication (2019) into segments of equal length, we found eight articles published between 1993 and 2001, 25 between 2002 and 2010, and 85 between 2011 and 2019. 
For European countries, we only found articles on kettle holes in Germany and Poland. This may be due to a lack of research on kettle holes in the other countries [72], but also because kettle holes in other countries are reported to be mostly located in non-agricultural areas, such as lake regions [73], esker areas, i.e., long, winding ridges of stratified sand and gravel [74,75], mountain areas [21,22] or on rockhead topography [76]. The majority of the papers we found focus on kettle holes in the USA and Canada. This can be attributed to the Prairie Pothole Region of North America, covering 700,000-900,000 $\mathrm{km}^{2}[77,78]$, which contains millions of kettle holes, a large portion of which are closely associated with agricultural cropland [79]. It extends into five U.S. states (North Dakota, South Dakota, Iowa, Minnesota and Montana) and three Canadian provinces (Alberta, Manitoba and Saskatchewan) [80].

The analyzed articles addressed eight ecosystem services supplied by kettle holes. Seven of these were regulation and maintenance services, while one was a cultural service ("Aesthetics from interactions with nature"). A frequency analysis of ES addressed in the review is displayed in Figure 1. It shows that in all countries analyzed, research on ES supplied by kettle holes focused on the four services: Nursery populations and habitats (CICES class 2.2.2.3), Hydrological cycle and flood control (CICES class 2.2.1.3), Chemical condition of freshwaters (CICES class 2.2.5.1), and Biotic remediation of wastes (CICES class 2.1.1.1), while the other four services were addressed in only a few papers.

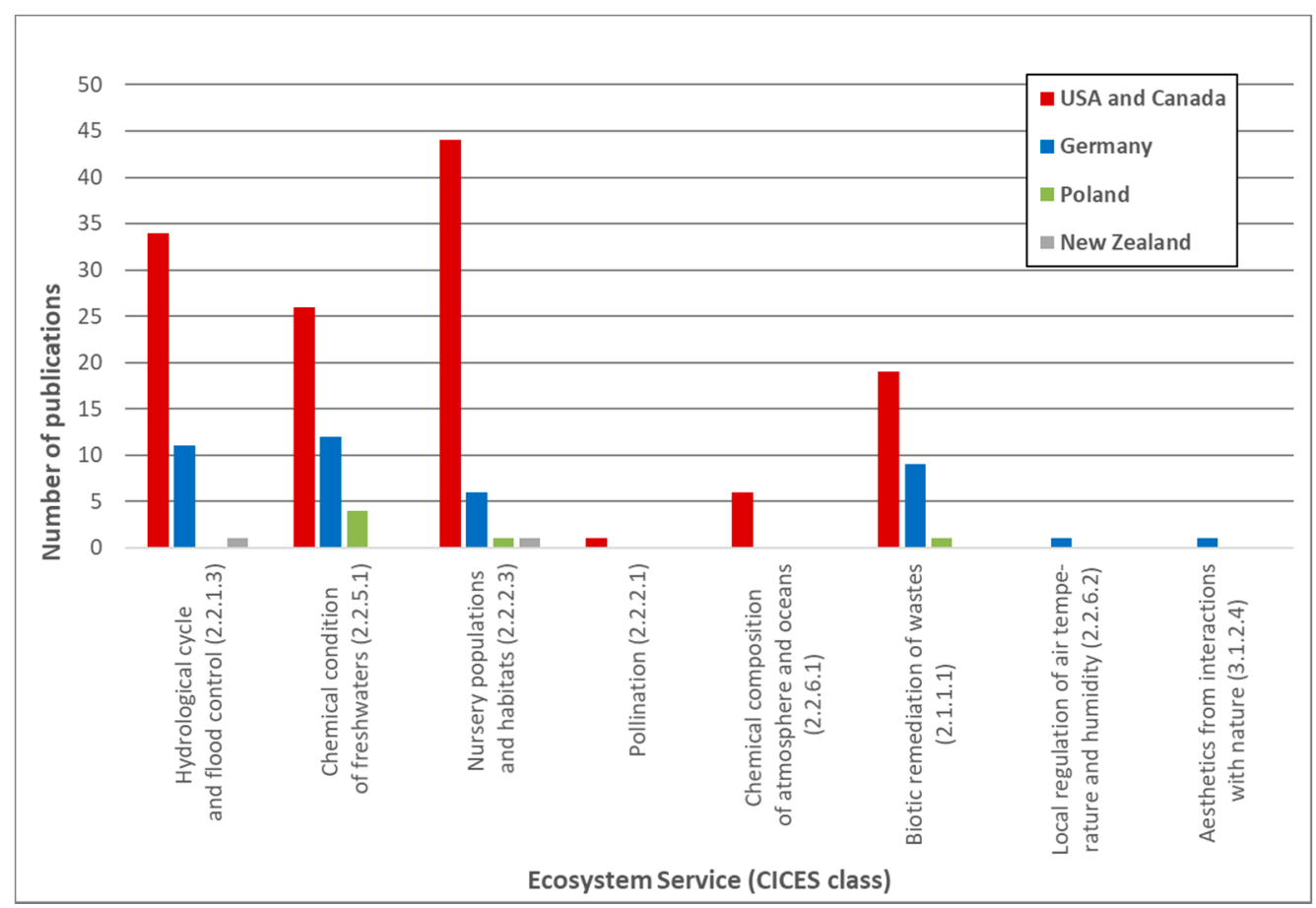

Figure 1. Number of articles in our review addressing ecosystem services supplied by kettle holes, per country. Ecosystem services were converted to the Common International Classification of Ecosystem Services (CICES), V5.1. Class names are simplified to aid intuitive understanding; class codes are provided in brackets.

Kettle holes in agricultural landscapes face multiple threats that may endanger their existence or impair their supply of ecosystem services. We identified climate change, tillage and erosion, fertilizer and pesticide application, as well as artificial drainage as relevant threat categories. A frequency analysis of threats to kettle holes addressed in the review is displayed in Figure 2. Results differed between countries: For the USA and Canada, the negative effects of drainage practices on kettle holes were documented most often. For Germany, most studies focused on effects of tillage and erosion, as well as effects of fertilizer and pesticide application. For Poland and New Zealand, the overall number of articles was too low to allow for interpretation. 


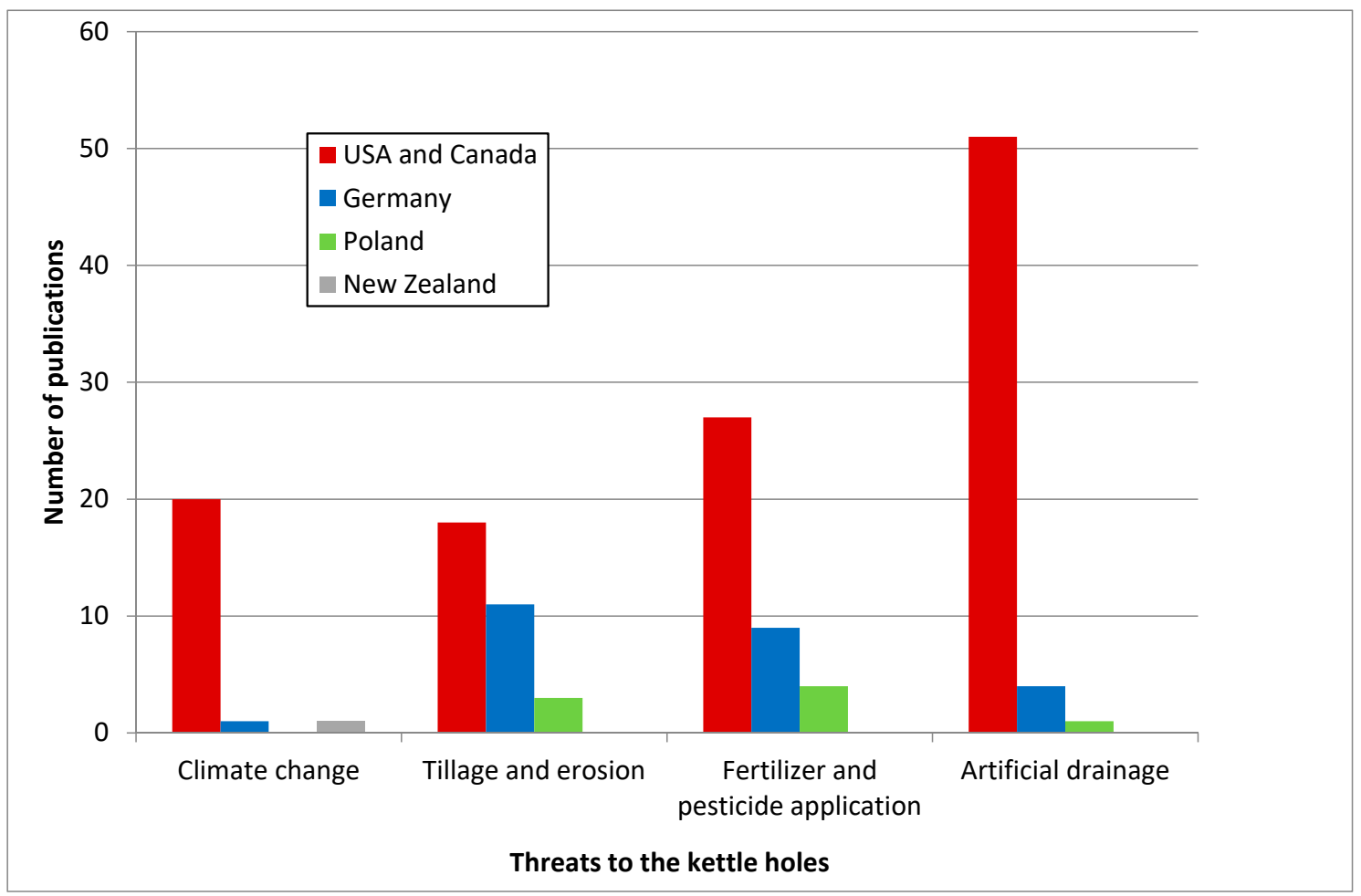

Figure 2. Number of articles in our review addressing threats to the kettle holes (climate change, tillage and erosion, fertilizer and pesticide application, artificial drainage), per country.

\subsection{Threats to Kettle Holes}

An overview of threats is provided in this section. Their effect on the supply of ecosystem services is then discussed in the following section.

\subsubsection{Climate Change}

Kettle holes are especially vulnerable to warming climate [81-83]. As the scenarios of the Intergovernmental Panel on Climate Change [39,40] project an increase in the mean temperature of the Earth's atmosphere, in many locations increased summer temperatures may lead to higher summer evapotranspiration rates, creating increased demands on groundwater and resulting in an earlier drying up of small water bodies [83]. This could lead to the loss of some kettle holes of smaller size, while bigger kettle holes could have longer dry cycles.

Effects of climate change on kettle holes also are mediated by land use in the catchment area. Management of land cover, i.e., grazed grassland or crops, could mitigate effects of climate warming by helping to maintain water levels $[84,85]$. However, climate change will also force agricultural management to adapt to changes in crop yields and global commodity prices [86,87]. Effects on kettle holes will therefore depend on the adaptations of agricultural management to climate change [85]. To protect the wide variety and high number of kettle holes, it is important to understand how they respond to changes in climate [88]. This knowledge can help to inform how and where conservation efforts are most effective, either in response to direct climate change effects or to abate indirect climate change effects caused by changes in agricultural management $[83,89,90]$.

\subsubsection{Agricultural Management}

Kettle holes have a longstanding connection with agricultural management. Anthropogenic influences such as forest clearance and tillage are considered to have added to kettle hole formation [4]. Material from tillage, including stones, was pushed to the sides of kettle holes, resulting in deeper depressions and more stable banks. However, many kettle holes worldwide have also been destroyed in 
the past due to land consolidation, such as filling them with soil to gain farmland [91-93]. Additionally, the ES supply of kettle holes is threatened by agricultural practices, such as tillage, causing mechanical disruption of the kettle hole basin or sedimentation into the kettle hole, exposure to fertilizers and pesticides, or artificial drainage.

\section{Tillage and Erosion}

Tillage may inflict mechanical damage to kettle hole structures or enhance erosion in areas with high erosivity. This can cause silting up, especially where delivery rates have been accelerated by anthropogenic activity or climate change [94]. Larger catchment areas induce higher surface runoff and erosion [38], while deeper kettle holes are more susceptible to bank erosion [93]. Additionally, some crops leave the soil more prone to erosion than others, such as crops grown in wide rows or tuber crops. Therefore, the choice of crop rotation is relevant $[95,96]$.

\section{Fertilizer and Pesticide Application}

For kettle holes in agricultural landscapes, the proximity of farmland often results in a transfer of contaminants such as fertilizers, pesticides and heavy metals into the water bodies. Where there is a direct link between kettle holes and groundwater layers, contamination may also spread from one water body to another $[97,98]$. Entry pathways are manifold, as agricultural contaminants can reach kettle holes via spray drift, aerial deposition, surface runoff, or groundwater flow $[99,100]$. Pesticides may kill plants, invertebrates and amphibians outright, or indirectly lead to mortality by weakening their immune systems [101-103]. Fertilizers and pesticides may impair both structure and function of microbial, macroinvertebrate and aquatic plant communities, which can significantly alter food webs [104]. Crop rotations are important because the amount of fertilizer and pesticides applied to fields, which may later enter into kettle holes, is crop specific. For example, in the USA, more pesticides and nitrogen fertilizer are used for corn than for any other extensively grown crop [105].

\section{Artificial Drainage}

Kettle holes are especially vulnerable to artificial drainage since they are situated within agricultural areas, have a small size, are isolated and may have a short hydroperiod $[106,107]$. Artificial drainage measures strongly alter the hydrology of catchments and can shorten the hydroperiod of kettle holes [5,108]. In the USA and Canada, research indicates that artificial drainage has the most serious impacts on kettle holes in agricultural areas [109,110], sometimes leading to the use of drained kettle hole areas as farmland. Small, isolated kettle holes are typically the first to be converted to agricultural crop production [111]. However, because kettle holes are depressions in the landscape, snowmelt or heavy rains can temporarily pond in them and cause yield losses [112].

\subsection{Ecosystem Services Supplied by Kettle Holes}

In this section, we address the ecosystem services supplied by kettle holes in agricultural landscapes. While the description of service supply is based on the results of our literature review, the discussion of linkages between service supply and agricultural management also draws on additional literature.

\subsubsection{Hydrological Cycle and Flood Control (CICES Code 2.2.1.3)}

Service: The wet-dry cycle characteristic for kettle holes is central for their ability to regulate water flows. Their ability to store additional water provides a valuable flood protection service. The water budget of a kettle hole is determined by winter and early spring inputs. These are primarily driven by snowmelt and runoff over partially frozen soils, direct precipitation and seasonal lateral flows $[27,113,114]$. Kettle holes with very small catchments maintain their water level only by rainfall [115]. Water losses occur through evapotranspiration, spillover and lateral shallow groundwater recharge $[113,116]$. The water level of kettle holes responds to extremely wet or extremely dry weather 
conditions [117-119]. While evaporation rates can be relatively high, for some kettle holes evaporation alone cannot explain their complete drying-out. Lateral groundwater flow to the wet margins of the water body is a dominant cause of water loss for kettle holes $[27,88,120]$.

Linkages with agricultural management: Water level fluctuations in kettle holes depend on soil and crop management, as well as drainage practices, and mostly follow weather and vegetation cycles [27]. In North America, a significantly lower water table as well as a lower fluctuation of the water levels was detected in kettle holes within grassland landscapes compared to kettle holes within tilled agricultural landscapes [121,122]. Flooding of kettle holes may also lead to crop damages in bordering fields. However, in dry years, kettle holes can act as water suppliers for surrounding crops [123]. This is consistent with findings by Kanwar et al. [124] and Ahmad et al. [125] who found a negative effect on crop yields during wet years and a potential yield improvement during dry years.

\subsubsection{Chemical Condition of Freshwaters (CICES Code 2.2.5.1)}

Service: Individually, kettle holes may seem insignificant, but collectively they play an important role in improving water quality in agricultural catchments [126]. Natural vegetation around kettle holes acts as a buffer strip, filtering particles and chemical inputs from runoff, with a positive effect on water quality. Kettle holes are sometimes connected to groundwater. While their filtering effect may improve the water quality, they may also be polluted by contaminated groundwater streams [127] or speed up groundwater pollution if they themselves are polluted.

Linkages with agricultural management: Given the intensification of agriculture, documented eutrophication of kettle holes is not surprising [128,129]. Water quality of kettle holes may be degraded as the result of waterborne or windborne sediment inputs [130], although maintenance of vegetation buffer strips may mitigate some impacts [131]. As some crops leave the soil more prone to erosion, and some crops are typically managed with higher amounts of pesticides and fertilizers than others, the choice of crop rotation affects water quality in kettle holes. Adapted management of agricultural fields around kettle holes is necessary to improve water quality. Regular monitoring of the water quality in kettle holes is desirable.

\subsubsection{Nursery Populations and Habitats (CICES Code 2.2.2.3)}

Service: This service also includes the protection of gene pools. Habitats for plants provided by kettle holes are often characterized by changing water levels. For instance, low water levels and occasional drying up (dry marsh phase) stimulate plant recruitment from diverse seed banks and increase productivity by mobilizing nutrients. In contrast, high water levels during deluges (lake marsh phase) cause turnover in plant populations, creating greater interspersion of emergent cover and open water, but lower overall productivity [83]. Like all temporary ponds, kettle holes are well known for their richness of annual plant species and often harbor numerous rare and endangered species [132,133]. For example, a study surveying 46 small kettle holes in Germany found 254 plant species, including 21 on the federal state's red list [134,135]. Besides supporting high plant diversity, kettle holes constitute a source of food and water for wild animals such as deer, wild boars, bats and migratory birds [136-139]. They also provide refuge to many rodents [140]. Kettle holes may function as important stepping stone biotopes in agricultural landscapes. The loss of even small wetlands areas in the landscape may therefore have a strong detrimental effect on biodiversity [141]. While enabling genetic exchange and preventing habitat fragmentation generally contributes to preserving species and gene pools, it may, under very specific circumstances, also have negative implications by facilitating the spread of diseases or invasive species [142].

Linkages with agricultural management: Negative effects of crop management on farmland biodiversity due to artificial drainage, tillage (e.g., increased turbidity and destruction of invertebrate eggs) [143] and high applications of pesticides and fertilizers are well documented [144,145]. Farmland intensification has led to a severe decline in the diversity of plant species [35] and amphibians [36] found around kettle holes. Balancing the interests of biodiversity conservation with agricultural 
production is important $[146,147]$. Therefore, Savoie et al. [148] suggest the harvest and energetic use of woody vegetation (shrubs and willows) around kettle holes as a solution. Biomass could be harvested on a 4-5-year cycle. Savoie et al. [148] state that beyond the generation of renewable energy, wood waste could contribute to moisture retention, soil nutrient cycling and the creation of habitat for wildlife, while biomass removal would contribute to reducing nutrient levels, thereby mitigating eutrophication.

\subsubsection{Pollination (CICES Code 2.2.2.1)}

Service: Research done by Vickruck et al. [149] demonstrates that small in-field wetland remnants, such as kettle holes, play an important role in supporting native pollinator communities in intensive agricultural landscapes. They are important nesting and foraging resources and support a highly diverse community of native bees [149]. Pollination services provided by wild bee species are crucial to the economy and food security of human populations, as well as playing a pivotal role in maintaining global biodiversity [150-152]. However, only one of the papers identified in our literature review addresses the value of kettle holes for pollinator communities. More research is desirable.

Linkages with agricultural management: Pollinator declines have been linked to multiple factors, including pesticides [153], parasites [154], climate change [155,156] and habitat loss [157], of which habitat loss is considered the most pervasive $[154,158,159]$. Reducing the application of pesticides in the direct vicinity of kettle holes and maintaining herbaceous buffer strips is likely to improve the suitability of kettle holes as habitats for pollinators.

\subsubsection{Chemical Composition of Atmosphere and Oceans (CICES Code 2.2.6.1)}

There is disagreement considering the role of kettle holes for climate change mitigation. Withey and van Kooten [160] highlight their potential to store methane and carbon dioxide. Organic carbon sequestration per unit area of sediment has been suggested to be at least an order of magnitude higher in small lakes (including kettle holes) than in larger lakes [161-163]. However, while kettle holes are prone to organic matter burial [164,165], dry-wet cycles help to counter silting up [166] as buried material is mineralized again during dry phases [167]. Consequently, Philips and Beeri [168], Gleason et al. [169], Pennock et al. [170], Brinson and Eckles [45] and Tangen et al. [171] indicate that kettle holes are net producers of greenhouse gases (GHG). The net effect of GHG production and mitigation by kettle holes strongly depends on wet-dry cycles and will therefore vary between kettle holes of different hydrological regimes.

Linkages with agricultural management: None of the reviewed articles addressed the influence of agriculture management on GHG production or mitigation by kettle holes. However, as management affects water levels and wet-dry cycles of kettles holes through land cover and potentially artificial drainage, it is likely to also affect their GHG balance.

\subsubsection{Biotic Remediation of Wastes (CICES Code 2.1.1.1)}

Service: This service is strongly correlated with the service Regulation of the chemical condition of freshwaters by living processes (CICES code 2.2.5.1). Kettle holes play an active role in nutrient cycling [172-174]. They use excess nutrients from fertilization of surrounding fields for biomass production. Other pollutants may be broken up by microorganisms living in the kettle holes. While nutrients and other pollutants may also be fixed within the sediment layer, this effect is of only minor importance where kettle holes fall dry for extended periods of time, strongly reducing the amount of sediment.

Linkages with agricultural management: Kettle holes are sinks for nutrients and contaminants from agricultural fields. While they may help to remediate organic wastes, their ability to do so depends on a healthy ecosystem. Management on the fields surrounding kettle holes should seek to minimize erosion, as well as fertilizer and pesticide inputs. 


\subsubsection{Local Regulation of Air Temperature and Humidity (CICES Code 2.2.6.2)}

Service: As small water bodies, kettle holes increase the humidity in their direct vicinity while the vegetation around them may lower wind speeds $[27,175]$.

Linkages with agricultural management: The colder and moister microclimate around kettle holes may help to mitigate drought effects in surrounding crop areas. However, it is also considered to be conducive to the growth of pathogenic fungi [176]. More research about the extent of services or disservices is desirable.

\subsubsection{Aesthetics from Interactions with Nature (CICES Code 3.1.2.4)}

Service: Kettle holes may increase the variability of otherwise monotonous agricultural landscapes and have a positive influence on landscape aesthetics. This service is only mentioned by Lipp [175], who considered it to contribute to the recreation potential of kettle holes.

Linkages with agricultural management: Linkages with agricultural management were not discussed in Lipp [175]. However, aesthetic perception of wetland areas is linked to visual attributes, such as transparency and color of water, as well as presence and appearance of aquatic vegetation [177]. Clear waters are generally preferred $[178,179]$. High nutrient inputs due to fertilizer application in surrounding fields may therefore lower the supply of this service while buffer strips with visually appealing vegetation may increase it.

\subsection{Policies and Conservation Programs}

As legal frameworks differ between countries, we used the German federal state of Brandenburg as a test case to examine the policies related to kettle holes. Several authors criticize protection strategies for kettle holes in Germany as inadequate because they are considered to be too specific with regard to the potential habitat functions of different kettle hole types $[4,6,36,180,181]$.

Our analysis of legal documents revealed that kettle holes are mentioned explicitly at the German national, the federal state and the district levels, while at European level they are only implicitly addressed as inland water bodies. Within the policy documents, only the supply of the ES "Nursery populations and habitats" is given as a justification for their protection (Table 2). This includes their role to connect biotopes by acting as stepping stone habitats. We found no reference to other ES supplied by kettle holes.

Although kettle holes are protected biotopes according to the German Federal Nature Conservation Act [58] and the Biotope Protection Regulation of Brandenburg [68] (Table 2), the extent of their protection is rather vague. For example, banks are included in the protection, but their width is not determined, so that there remains uncertainty about the spatial limits of the biotope. Drainage management is not clearly regulated, and it is hard to determine under which circumstances it is allowed. Whether disturbances are considered significant or not has to be assessed based on Annex I of the European Environmental Liability Directive [53], accounting for the baseline condition of the biotope and natural fluctuation rates. While regular monitoring is a prerequisite to conduct such assessments, this is not addressed in the legal framework. Quite similarly, a lack of monitoring has also been identified as an obstacle to efficient wetland regulations in the USA and Canada [182]. 
Table 2. Ecosystem services stated as reasons for the protection of kettle holes in policy documents at European, German national and German federal state level.

\begin{tabular}{|c|c|c|c|}
\hline Policy Document & Administrative Level & Citation (German Texts Are Provided in Translation) & CICES Class \\
\hline $\begin{array}{l}\text { EU Habitats Directive [52], Article } 10 \\
\text { http://bit.ly/2PkFdII }\end{array}$ & European Directive & $\begin{array}{l}\text { Member States shall endeavor, where they consider it necessary, }[\ldots] \text { to } \\
\text { encourage the management of features of the landscape which are of } \\
\text { major importance for wild fauna and flora. Such features are those } \\
\text { which, by virtue of }[\ldots] \text { their function as stepping stones (such as } \\
\text { ponds or small woods), are essential for the migration, dispersal and } \\
\text { genetic exchange of wild species. }\end{array}$ & $\begin{array}{l}\text { Nursery populations and habitats } \\
\text { (CICES code 2.2.2.3) }\end{array}$ \\
\hline $\begin{array}{l}\text { Federal Nature Conservation Act [58] §21 (5) } \\
\text { http://bit.ly/2Rwh2ru }\end{array}$ & National Law & $\begin{array}{l}\text { [... ] Surface water bodies including their riparian strips, banks and } \\
\text { wetlands have to be preserved as biotopes for naturally occurring } \\
\text { animal and plant species, and developed in a way that they can fulfill } \\
\text { their function as stepping stones on a large scale. }\end{array}$ & $\begin{array}{l}\text { Nursery populations and habitats } \\
\text { (CICES code 2.2.2.3) }\end{array}$ \\
\hline $\begin{array}{c}\text { Federal Nature Conservation Act [58] } \$ 30(1) \\
\text { http://bit.ly/2PiUHwV }\end{array}$ & National Law & $\begin{array}{c}\text { Certain parts of nature and landscape with special importance as } \\
\text { biotopes are protected. Measures leading to destruction/significant } \\
\text { perturbation of the following biotopes are prohibited: } 1 \text {. Natural or } \\
\text { semi-natural inland water bodies including their banks and their } \\
\text { natural or semi-natural waterfront vegetation as well as their natural or } \\
\text { semi-natural siltation areas, cut-off meanders and regularly flooded area } \\
{[\ldots]}\end{array}$ & $\begin{array}{l}\text { Nursery populations and habitats } \\
\text { (CICES code 2.2.2.3) }\end{array}$ \\
\hline $\begin{array}{l}\text { Biotope Protection Regulation of Brandenburg [68] } \\
\S 1(1.2) \mathrm{http}: / / \text { bit.ly/31HA7sx }\end{array}$ & Federal State Regulation & $\begin{array}{l}\text { Legal protection covers }[\ldots \text { ] kettle holes }[\ldots \text { ] inhabited by typical } \\
\text { plant and animal species [these are defined in the same section] }\end{array}$ & $\begin{array}{l}\text { Nursery populations and habitats } \\
\text { (CICES code 2.2.2.3) }\end{array}$ \\
\hline
\end{tabular}


Regulations for fertilizer and pesticide application are not specifically adapted to kettle holes, so that general regulations for water bodies apply. The German Fertilizer Ordinance [60] prescribes a minimum distance of 1-5 m from the water's edge when spreading nitrogen or phosphorus containing fertilizers, depending on slope, machinery and crop. The use of pesticide-containing substances listed in Annexes 2 and 3 of the Plant Protection Implementing Regulation [63] (e.g., glyphosate and important neonicotinoids) is prohibited in protected biotopes, but there are no additional restrictions concerning their use in the areas surrounding these biotopes. This implies a potential risk, especially with regard to the lack of a clear definition of the borders of kettle hole biotopes.

Legislation pertaining to the European Union's Common Agricultural Policy (CAP) is highly relevant because it defines "good agricultural and environmental conditions" (GAEC) on farms as a prerequisite for European farmers to receive support payments. Economically, the majority of European farmers depend on these payments. In order to meet the European standards for GAEC ([56], Annex II), the German Agricultural Payments Obligations Regulation explicitly prohibits the removal of kettle holes of $2000 \mathrm{~m}^{2}$ maximum size ([65] §8 (1) 4., relating to GAEC 7). The non-compliance with the CAP legislation can result in a reduction of the agricultural payments ([56], Article 77). Additionally, since 2015 direct payments under the CAP contain a greening component. Farmers with 15 or more hectares of cropland are required to manage at least $5 \%$ of their cropland as ecological focus areas (EFA) to avail of these payments. Kettle holes up to a size of $2000 \mathrm{~m}^{2}$ can be counted as EFA. Under the second pillar of the CAP, Agri-Environment and Climate Schemes (AECSs) can be used to compensate farmers for costs and income losses from voluntary measures that protect the environment and/or the global climate. Several of these measures, such as installing flower strips at field margins or switching to organic farming, can also help to alleviate kettle hole threats.

Kettle holes that are located within Flora, Fauna and Habitat (FFH) sites are protected indirectly, in accordance with protection requirements, e.g., endangered species inhabiting the area (c.f. [52], Annex IV). In this case, specific regulations may define kettle hole borders and regulate management of surrounding areas in order to achieve conservation targets. Regulations may include obligations for riparian strips with a width of $20 \mathrm{~m}$ where no fertilizer or pesticide application is allowed, prohibit the filling up of temporary small water bodies or prohibit the discharge of non-purified, nutrient-rich water (e.g., $[183,184])$. This indicates that the negative impacts of the regulated management practices are acknowledged by governmental authorities. However, the vast majority of kettle holes in Brandenburg does not benefit from such an extended protection.

\subsection{Policy Recommendations}

While kettle holes supply ecosystem services that by definition benefit society, the costs of preserving them fall to the farmers. Kettle holes occupy land that could otherwise be put to productive use, and they may pose operational challenges and costs, for example, related to difficulties with maneuvering large machinery around kettle holes $[92,185]$.

Consultation with farmers to jointly identify options for kettle hole preservation is therefore desirable. This should be combined with improved science communication to increase awareness among farmers of the benefits provided by kettle holes. Subsidies or agri-environmental payments could be a way to offset farmers' costs of maintaining kettle holes and the ecosystem services they supply [6]. These subsidies could support measures of ecological intensification such as conservation tillage practices to prevent soil erosion, legume rich crop rotations to reduce the need for chemical fertilizer input, or wide crop rotations to reduce frequency and strength of pest and disease incidents, thereby reducing pesticide applications [186]. Subsidies could also be provided for maintaining and managing buffer strips, or for managing fields surrounding kettle holes extensively. Frielinghaus and Vahrson [187] report the positive effects of a subsidized, temporal set-aside of agricultural land to improve the water quality in polluted kettle holes. However, the large number of kettle holes in agricultural landscapes would make it very costly to fund subsidized management in all surrounding areas. Assessing the ES currently and potentially provided by specific kettle holes may help to assign 
funding priorities. If this were combined with a subsidy rotation scheme, an even higher number of kettle holes could be supported. This would mean offering subsidies for agricultural areas surrounding a specific kettle hole for a limited number of years, giving the ecosystem time to recover.

Farmers may be interested in these types of subsidies. According to Raatz et al. [123], yields close to kettle hole borders are lower than in the rest of the field due to legally required minimum distances from water bodies for applying pesticides and fertilizers. Additionally, kettle holes are often too wet, resulting in lower crop yields and potential crop losses. Assessments should determine the minimal financial and bureaucratic requirements, so that farmers would be motivated to apply.

\section{Conclusions and Recommendations}

The body of scientific literature we reviewed indicates that kettle holes supply multiple ecosystem services. There is a strong focus on four services: hydrological cycle and flood control (CICES class 2.2.1.3), chemical condition of freshwaters (CICES class 2.2.5.1), nursery populations and habitats (CICES class 2.2.2.3) and biotic remediation of wastes (CICES class 2.1.1.1).

However, the body of research addressing supply of the services pollination (CICES class 2.2.2.1), regulation of chemical composition of atmosphere and oceans (CICES class 2.2.6.1), local regulation of air temperature and humidity (CICES class 2.2.6.2) and aesthetics from interactions with nature (CICES class 3.1.2.4) is very limited. Further research in this regard is desirable. In policy documents pertaining to the protection of kettle holes in Germany and in the German federal state of Brandenburg, kettle holes are mainly recognized for their ability to provide habitats and to act as stepping stone biotopes.

Water regime, water quality and habitat function of kettle holes can be highly impaired by intensive agricultural management in fields surrounding kettle holes if these practices cause erosion or include high levels of fertilizer and pesticide application. A loss of kettle holes and of the ecosystem services they supply could impact the regulation of water flows in agricultural landscapes and lead to a loss of habitats and biodiversity, including habitats and biodiversity of endangered amphibian species.

Kettle holes need to be addressed more precisely in policy documents and conservation programs. Policies are required to encourage farmers to better adapt their management in the areas surrounding kettle holes in order to improve kettle hole protection. As farmers can profit from the ecosystem services supplied by kettle holes only in a very limited way, subsidies may provide an important means for balancing economic and environmental considerations.

Providing society and policy makers with information about the ecosystem services supplied by kettle holes and about the threats to this supply contributes to informed decision making and sustainable management. This will also require more field data. Especially for fertilizer or pesticide applications, data are usually not publicly available in Germany. More effective monitoring of kettle holes will be of critical importance with regard to understanding and predicting responses of kettle holes to different types of agricultural management, to raise awareness for kettle hole threats, enable enforcement of policies and ensure compliance with conservation requirements.

Author Contributions: F.V., C.P. and K.H. developed the original idea and conceptualized the manuscript. F.V. conducted the review of scientific literature; F.V. and C.P. wrote the manuscript; V.S. conducted the review of policy documents. All authors have read and agreed to the published version of the manuscript.

Funding: This research has been funded by the German Federal Foundation for the Environment (Deutsche Bundesstiftung Umwelt-DBU) through their fellowships program for university graduates from Central and Eastern Europe (CEE) and by the Leibniz Centre for Agricultural Landscape Research (ZALF) through the integrated priority project SWBTrans: "Smart Use of Heterogeneities of Agricultural Landscapes".

Acknowledgments: We would like to thank Marlene Pätzig, Michael Glemnitz, Marina Müller, Dagmar Balla, Jörg Steidl, Katrin Daedlow, Alevtina Evgrafova, Thomas Kalettka, Angelique Kangondo, Sebastian Ristau, Sebastian Weigl, and three anonymous reviewers for helpful comments and suggestions, as well as Joseph Macpherson for language correction. Their efforts are greatly appreciated.

Conflicts of Interest: The authors declare no conflict of interest. 


\section{References}

1. Burkhard, B.; Maes, J. Mapping Ecosystem Services; Burkhard, B., Maes, J., Eds.; Pensoft Publishers: Sofia, Bulgaria, 2017. [CrossRef]

2. Watznauer, A. Wörterbuch der Geowissenschaften Deutsch-Englisch; Verlag Harri Deutsch: Thun and Frankfurt/Main, Germany, 1989; Volume 3, p. 387.

3. Mitsch, W.J.; Gosselink, J.G. Wetlands; Van Nostrand Reinhold: New York, NY, USA, 1993; p. 722.

4. Kalettka, T.; Rudat, C.; Quast, J. 18 "Potholes" in Northeast German agro-landscapes: Functions, land use impacts, and protection strategies. In Ecosystem Approaches to Landscape Management in Central Europe; Tenhunen, J.D., Lenz, R., Hentschel, R., Eds.; (Ecological studies); Springer: Berlin, Germany, 2001; Volume 147, pp. 291-298.

5. Merbach, W.; Kalettka, T.; Rudat, C.; Augustin, J. Trace gas emissions from riparian areas of small eutrophic inland waters in Northeast-Germany. In Wetlands in Central Europe; Springer Science and Business Media LLC: Berlin, Germany, 2002; pp. 235-244.

6. Kalettka, T.; Rudat, C. Hydrogeomorphic types of glacially created kettle holes in North-East Germany. Limnologica. 2006, 36, 54-64. [CrossRef]

7. Filion, L.; Bègin, Y. Recent paludification of kettle holes on the central isjands of Lake Bienville, northern Quebec, Canada. Holocene 1998, 8, 91-96. [CrossRef]

8. Winter, T.C. Hydrologic studies of wetlands in the northern prairie. In Northern Prairie Wetlands; Van der Valk, A.G., Ed.; Iowa State University Press: Ames, IA, USA, 1989; pp. 16-54.

9. Tiner, R.W. Geographically isolated wetlands of the United States. Wetlands 2003, 23, 494-516. [CrossRef]

10. Fay, H. Formation of kettle holes following a glacial outburst flood, Skeiðarársandur. In The Extremes of the Extremes: Extraordinary Floods; Snorrison, Á., Finsdóttir, H.P., Moss, M.E., Eds.; IAHS Press: Wallingford, UK, 2002; p. 205.

11. Kilinc, S.; Moss, B. Whitemere, a lake that defies some conventions about nutrients. Freshw. Biol. 2002, 47, 207-218. [CrossRef]

12. Nichol, D. Environmental changes within kettle holes at Borras Bog triggered by construction of the A5156 Llanypwll Link Road, North Wales. Eng. Geol. 2001, 59, 73-82. [CrossRef]

13. Kelly, T.J.; Hardiman, M.; Lovelady, M.; Lowe, J.; Matthews, I.P.; Blockley, S.P.E. Scottish early Holocene vegetation dynamics based on pollen and tephra records from Inverlair and Loch Etteridge, Inverness-shire. Proc. Geol. Assoc. 2017, 128, 125-135. [CrossRef]

14. Eilertsen, R.; Boe, R.; Hermanns, R.; Longva, O.; Dahlgren, S. Kettle holes, 'dead-ice' topography and eskers on a lake floor in Telemark, southern Norway. Geol. Soc. Lond. Mem. 2016, 46, 113-114. [CrossRef]

15. Nilsson, A.N. Species richness and succession of aquatic beetles in some kettle-hole ponds in northern Sweden. Ecography 1984, 7, 149-156. [CrossRef]

16. Reinikainen, A.; Lindholm, T.; Vasander, H. Ecological variation of mire site types in the small kettle-hole mire Heinisuo, southern Finland. Ann. Bot. Fenn. 1984, 21, 79-101.

17. Noe-Nygaard, N.; Milàn, J.; Hede, M.U.; Holm, J. A reindeer track from a drill core, and lake basin development of the Late Glacial Lille Slotseng kettle-hole basin, South-East Jylland, Denmark. Bull. Geol. Soc. Den. 2007, 55, 85-95.

18. Borówka, R. The pattern and magnitude of denudation in interplateau sedimentary basins during the Late Vistulian and Holocene. Ser. Geogr. 1992, 54, 1-177.

19. Kisielienè, D. Floristic complexes from lacustrine sediments of Merkinè Interglacial and Early Nemunas Glacial in the borehole Medininkai-117. Geologija 1999, 29, 50-56.

20. Punning, J.; Koff, T.; Ilomets, M.; Jotgi, J. The relative influence of local, extra-local, and regional factors on organic sedimentation in the Vällamäe kettle hole, Estonia. Boreas 2008, 24, 65-80. [CrossRef]

21. Götz, J.; Salcher, B.; Starnberger, R.; Krisai, R. Geophysical, topographic and stratigraphic analyses of perialpine kettles and implications for postglacial mire formation. Geogr. Ann. Ser. A Phys. Geogr. 2018, 100, 254-271. [CrossRef]

22. Corti, G.; Cocco, S.; Basili, M.; Cioci, C.; Warburton, J.; Agnelli, A. Soil formation in kettle holes from high altitudes in central Apennines, Italy. Geoderma 2012, 170, 280-294. [CrossRef]

23. Velić, J.; Velić, I.; Kljajo, D. Sedimentary bodies, forms and occurrences in the Tudorevo and Mirovo glacial deposits of northern Velebit (Croatia). Geol. Croat. 2011, 64, 1-16. [CrossRef] 
24. Tsyganov, A.N.; Kupriyanov, D.A.; Babeshko, K.V.; Borisova, T.V.; A Chernyshov, V.; Volkova, E.M.; A Chekova, D.; Mazei, Y.A.; Novenko, E.Y. Autogenic and allogenic factors affecting development of a floating Sphagnum-dominated peat mat in a karst pond basin. Holocene 2018, 29, 120-129. [CrossRef]

25. James, A.; Binny, R.N.; Lee, W.G.; Payne, J.; Stringer, N.; Holland, E.P. Predicting water levels in ephemeral wetlands under climate change scenarios. Theor. Ecol. 2019, 12, 427-435. [CrossRef]

26. Hayashi, M.; Van Der Kamp, G.; Schmidt, R. Focused infiltration of snowmelt water in partially frozen soil under small depressions. J. Hydrol. 2003, 270, 214-229. [CrossRef]

27. Gerke, H.H.; Koszinski, S.; Kalettka, T.; Sommer, M. Structures and hydrologic function of soil landscapes with kettle holes using an integrated hydropedological approach. J. Hydrol. 2010, 393, 123-132. [CrossRef]

28. Rittenhouse, T.A.G.; Semlitsch, R.D. Distribution of amphibians in terrestrial habitat surrounding wetlands. Wetlands 2007, 27, 153-161. [CrossRef]

29. Kłosowski, S.; Jabłońska, E. Aquatic and swamp plant communities as indicators of habitat properties of astatic water bodies in north-eastern Poland. Limnologica 2009, 39, 115-127. [CrossRef]

30. Gleason, R.A.; Euliss, N.H.; Tangen, B.A.; Laubhan, M.K.; Browne, B.A. USDA conservation program and practice effects on wetland ecosystem services in the Prairie Pothole Region. Ecol. Appl. 2011, 21, S65-S81. [CrossRef]

31. Tranvik, L.J.; Downing, J.A.; Cotner, J.B.; Loiselle, S.; Striegl, R.G.; Ballatore, T.J.; Dillon, P.; Finlay, K.; Fortino, K.; Knoll, L.B. Lakes and reservoirs as regulators of carbon cycling and climate. Limnol. Oceanogr. 2009, 54, 2298-2314. [CrossRef]

32. Aufdenkampe, A.K.; Mayorga, E.; A Raymond, P.; Melack, J.M.; Doney, S.C.; Alin, S.; Aalto, R.E.; Yoo, K. Riverine coupling of biogeochemical cycles between land, oceans, and atmosphere. Front. Ecol. Environ. 2011, 9, 53-60. [CrossRef]

33. Premke, K.; Attermeyer, K.; Augustin, J.; Cabezas, A.; Casper, P.; Deumlich, D.; Gelbrecht, J.; Gerke, H.H.; Gessler, A.; Grossart, H.-P.; et al. The importance of landscape diversity for carbon fluxes at the landscape level: Small-scale heterogeneity matters. Wiley Interdiscip. Rev. Water 2016, 3, 601-617. [CrossRef]

34. Céréghino, R.; Biggs, J.; Oertli, B.; Declerck, S.A.J. The ecology of European ponds: Defining the characteristics of a neglected freshwater habitat. In Pond Conservation in Europe; Springer Science and Business Media LLC: Berlin, Germany, 2007; pp. 1-6.

35. Altenfelder, S.; Raabe, U.; Albrecht, H. Effects of water regime and agricultural land use on diversity and species composition of vascular plants inhabiting temporary ponds in northeastern Germany. Tuexenia 2014, 34, 145-162. [CrossRef]

36. Berger, G.; Pfeffer, H.; Kalettka, T. Amphibienschutz in kleingewässerreichen Ackerbaugebieten: Grundlagen Konflikte Lösungen (Conservation of amphibians in agricultural landscapes rich in small water bodies); Natur \& Text: Rangsdorf, Germany, 2011.

37. Lischeid, G.; Kalettka, T. Grasping the heterogeneity of kettle hole water quality in Northeast Germany. Hydrobiologia 2011, 689, 63-77. [CrossRef]

38. Pätzig, M.; Kalettka, T.; Glemnitz, M.; Berger, G. What governs macrophyte species richness in kettle hole types? A case study from Northeast Germany. Limnologica 2012, 42, 340-354. [CrossRef]

39. Solomon, S.; Qin, D.; Manning, M.; Chen, Z.; Marquis, M.; Averyt, K.B.; Tignor, M.; Miller, H.L. (Eds.) Climate Change 2007-The Physical Science Basis. Contribution of Working Group I to the Fourth Assessment Report of the Intergovernmental Panel on Climate Change; Cambridge University Press: Cambridge, UK; New York, NY, USA, 2007.

40. Pachauri, R.K.; Meyer, L.A.; Vicente, R.B.; John, B.; Wolfgang, L.A.; Renate, C.; John, A.C.; Leon, C.; Qin, D.; Purnamita, D.; et al. Climate Change 2014-Synthesis Report. Contribution of Working Groups I, II and III to the Fifth Assessment Report of the Intergovernmental Panel on Climate Change; Pachauri, R.K., Meyer, L.A., Eds.; IPCC: Geneva, Switzerland, 2014; p. 151.

41. Klafs, G.; Lippert, K. Landschaftselemente Mecklenburg-Vorpommerns im hundertjährigen Vergleich, Teil 1: Ackerkleinhohlformen. Naturschutzarbeit Mecklenburg-Vorpommern 2000, 43, 58-65.

42. Klafs, G.; Jeschke, L.; Schmidt, H. Genese und Systematik wasserführender Ackerhohlformen in den Nordbezirken der DDR. Arch. Naturschutz Landschaftsforschung 1973, 13, 287-302.

43. Grim, S.; Sirocko, F. Natural depressions on modern topography in Schleswig-Holstein (Northern Germany)-indicators for recent crustal movements or "only" kettle holes? [Natürliche Hohlformen an der 
rezenten Oberfläche Schleswig-Holsteins-Indikatoren für rezente Krustenmobilität oder "nur" Toteislöcher?]. Z. Dt. Ges. Geowiss. 2012, 163, 469-481.

44. Wieckowska, M.; Dörfler, W.; Kirleis, W. Holocene history of environment and human impact on two islands in the Ostholstein lakeland area, Northern Germany. Veg. Hist. Archaeobot. 2011, 21, 303-320. [CrossRef]

45. Brinson, M.M.; Eckles, S.D. U.S. Department of Agriculture conservation program and practice effects on wetland ecosystem services: A synthesis. Ecol. Appl. 2011, 21, S116-S127. [CrossRef]

46. Upadhyay, P.; Pruski, L.; Kaleita, A.L.; Soupir, M.L. Evaluation of AnnAGNPS for simulating the inundation of drained and farmed potholes in the Prairie Pothole Region of Iowa. Agric. Water Manag. 2018, 204, $38-46$. [CrossRef]

47. Brunet, N.N.; Westbrook, C.J. Wetland drainage in the Canadian prairies: Nutrient, salt and bacteria characteristics. Agric. Ecosyst. Environ. 2012, 146, 1-12. [CrossRef]

48. Haines-Young, R.; Potschin, M.B. Common International Classification of Ecosystem Services (CICES) V5. 1 and Guidance on the Application of the Revised Structure. 2018. Available online: https://cices.eu/ (accessed on 2 September 2020).

49. Czúcz, B.; Arany, I.; Potschin-Young, M.; Bereczki, K.; Kertész, M.; Kiss, M.; Aszalós, R.; Haines-Young, R. Where concepts meet the real world: A systematic review of ecosystem service indicators and their classification using CICES. Ecosyst. Serv. 2018, 29, 145-157. [CrossRef]

50. La Notte, A.; Rhodes, C. The theoretical frameworks behind integrated environmental, ecosystem, and economic accounting systems and their classifications. Environ. Impact Assess. Rev. 2020, 80, 106317. [CrossRef]

51. Directive 2000/60/EC of the European Parliament and of the Council of 23 October 2000 Establishing a Framework for Community Action in the Field of Water Policy. O J L 327, 22/12/2000, pp. 1-73. EUR-Lex Home Page. Available online: http://bit.ly/36DYCcV (accessed on 2 September 2020).

52. Council Directive 92/43/EEC of 21 May 1992 on the Conservation of Natural Habitats and of Wild Fauna and Flora. O J L 206, 22/7/1992, p. 7. EUR-Lex Home Page. Available online: http://bit.ly/2PkFdII (accessed on 2 September 2020).

53. Directive 2004/35/CE of the European Parliament and of the Council of 21 April 2004 on Environmental Liability with Regard to the Prevention and Remedying of Environmental Damage. O J L 143, 30/04/2004, pp. 56-75. EUR-Lex Home Page. Available online: http://bit.ly/36FPDb4 (accessed on 2 September 2020).

54. Council Directive 91/676/EEC of 12 December 1991 Concerning the Protection of Waters against Pollution Caused by Nitrates from Agricultural Sources. O J L 375, 31/12/1991, pp. 1-8. EUR-Lex Home Page. Available online: http://bit.ly/38Mwplv (accessed on 2 September 2020).

55. Directive 2009/128/EC of the European Parliament and of the Council of 21 October 2009 Establishing a Framework for Community Action to Achieve the Sustainable Use of Pesticides (Text with EEA Relevance). O J L 309, 24/11/2009, p. 71. EUR-Lex Home Page. Available online: http://bit.ly/2GwOXKi (accessed on 2 September 2020).

56. Regulation (EU) No 1306/2013 of the European Parliament and of the Council on the Financing, Management and Monitoring of the Common Agricultural Policy. O J L 347, 20/12/2013, pp. 549-607. EUR-Lex Home Page. Available online: https://bit.ly/2MwTkba (accessed on 2 September 2020).

57. German Water Resources Act: Wasserhaushaltsgesetz (WHG) vom 31. Juli 2009. BGBl. I, p. 2585. Available online: http://bit.ly/2vuA7lp (accessed on 2 September 2020).

58. Federal Nature Conservation Act of Germany: Bundesnaturschutzgesetz (BNatSchG) vom 29. Juli 2009. BGBl. I, p. 2542. Available online: http://bit.ly/3aSTSU6 (accessed on 2 September 2020).

59. German Environmental Damage Act: Umweltschadensgesetz (USchadG) vom 10. Mai 2007. BGB1. I, p. 666. Available online: http://bit.ly/2U6Psmj (accessed on 2 September 2020).

60. German Fertiliser Ordinance: Düngeverordnung (DüV) vom 26. Mai 2017. BGBl. I, p. 1305. Available online: http://bit.ly/2tWrj7q (accessed on 2 September 2020).

61. German Fertilizer Act: Düngegesetz (DüngG) vom 9. Januar 2009. BGBl. I, p. 54, 136. Available online: http://bit.ly/38JC5fT (accessed on 2 September 2020).

62. German Plant Protection Act: Pflanzenschutzgesetz (PflSchG) vom 6. Februar 2012. BGBl. I, p. $148,1281$. Available online: http://bit.ly/2Rya99f (accessed on 2 September 2020). 
63. German Plant Protection Implementing Regulation: Pflanzenschutz-Anwendungsverordnung (PflSchAnwV) vom 10. November 1992. BGBl. I, p. 1887. Available online: http://bit.ly/37CY200 (accessed on 2 September 2020).

64. Agricultural Payments Obligations Law: Agrarzahlungen-Verpflichtungengesetz vom 2. Dezember 2014. BGBl. I, p. 1928. Available online: https://bit.ly/2AFwQ1G (accessed on 2 September 2020).

65. Agricultural Payments Obligations Regulation: Agrarzahlungen-Verpflichtungenverordnung vom 17. Dezember 2014. BAnz AT 23.12.2014 V1. Available online: https://bit.ly/3cyU8qS (accessed on 2 September 2020).

66. Water Act of Brandenburg: Brandenburgisches Wassergesetz (BbgWG) in der Fassung der Bekanntmachung vom 2. März 2012. GVBl. I/12, [Nr. 20]. Available online: http://bit.ly/31F56pi (accessed on 2 September 2020).

67. Organic Act of Brandenburg implementing the Federal Nature Conservation Act: Brandenburgisches Ausführungsgesetz zum Bundesnaturschutzgesetz (Brandenburgisches Naturschutzausführungsgesetz-BbgNatSchAG) vom 21. Januar 2013. GVBl. I/13, [Nr. 3]. Available online: http://bit.ly/30e8fgL (accessed on 2 September 2020).

68. Biotope Protection Regulation of Brandenburg: Verordnung zu den gesetzlich geschützten Biotopen (Biotopschutzverordnung) vom 7. August 2006. GVBl. II/06, [Nr. 25], p. 438. Available online: http://bit.ly/31HA7sx (accessed on 2 September 2020).

69. Nature Conservation Act of Brandenburg (expired): Gesetz über den Naturschutz und die Landschaftspflege im Land Brandenburg (Brandenburgisches Naturschutzgesetz-BbgNatSchG) in der Fassung der Bekanntmachung vom 26. Mai 2004. GVBl. I/04, [Nr. 16], p.350. Available online: http://bit.ly/33ItTe4 (accessed on 2 September 2020).

70. Conservation Target Regulations: Erhaltungszielverordnungen (1.-26. ErhZV) für FFH-Gebiete in Brandenburg. Available online: http://bit.ly/2S4hmNq (accessed on 2 September 2020).

71. Ministerium für Landwirtschaft, Umwelt und Klimaschutz (MLUK) Landschaftsrahmenpläne. 2020. Available online: https://bit.ly/2BeF5Wh (accessed on 2 September 2020).

72. Lemdahl, G.; Buckland, P.I.; Mortensen, M.F. Lateglacial insect assemblages from the Palaeolithic site Slotseng: New evidence concerning climate and environment in SW Denmark. Quat. Int. 2014, 341, 172-183. [CrossRef]

73. Høgaas, F.; Longva, O. Mega deposits and erosive features related to the glacial lake Nedre Glomsjø outburst flood, southeastern Norway. Quat. Sci. Rev. 2016, 151, 273-291. [CrossRef]

74. Matthews, J.A.; Seppälä, M.; Dresser, P.Q. Holocene solifluction, climate variation and fire in a subarctic landscape at Pippokangas, Finnish Lapland, based on radiocarbon-dated buried charcoal. J. Quat. Sci. 2005, 20, 533-548. [CrossRef]

75. Maries, G.; Ahokangas, E.; Mäkinen, J.; Pasanen, A.; Malehmir, A. Interlobate esker architecture and related hydrogeological features derived from a combination of high-resolution reflection seismics and refraction tomography, Virttaankangas, southwest Finland. Hydrogeol. J. 2016, 25, 829-845. [CrossRef]

76. Harris, C. Glacial deposits at Wylfa Head, Anglesey, North Wales: Evidence for Late Devensian deposition in a non-marine environment. J. Quat. Sci. 1991, 6, 67-77. [CrossRef]

77. Van Der Valk, A.G. Water-level fluctuations in North American prairie wetlands. Hydrobiologia 2005, 539, 171-188. [CrossRef]

78. Goldhaber, M.; Mills, C.; Stricker, C.A.; Morrison, J. The role of critical zone processes in the evolution of the Prairie Pothole Region wetlands. Appl. Geochem. 2011, 26, S32-S35. [CrossRef]

79. Messing, P.G.; Farenhorst, A.; Waite, D.T.; McQueen, D.R.; Sproull, J.F.; Humphries, D.A.; Thompson, L.L. Predicting wetland contamination from atmospheric deposition measurements of pesticides in the Canadian Prairie Pothole region. Atmos. Environ. 2011, 45, 7227-7234. [CrossRef]

80. Gleason, R.A.; Laubhan, M.K.; Euliss, N.H., Jr. (Eds.) Ecosystem Services Derived from Wetland Conservation Practices in the United States Prairie Pothole Region with an Emphasis on the U.S. Department of Agriculture Conservation Reserve and Wetlands Reserve Programs; Professional Paper Series, 1745; US Geological Survey: Reston, VA, USA, 2008; p. 58.

81. Larson, D.L. Effects of climate on numbers of northern prairie wetlands. Clim. Chang. 1995, 30, 169-180. [CrossRef]

82. Sorenson, L.G.; Goldberg, R.; Root, T.L.; Anderson, M.G. Potential Effects of Global Warming on Waterfowl Populations Breeding in the Northern Great Plains. Clim. Chang. 1998, 40, 343-369. [CrossRef] 
83. Johnson, W.C.; Millett, B.; Gilmanov, T.; Voldseth, R.A.; Guntenspergen, G.R.; Naugle, D.E. Vulnerability of Northern Prairie Wetlands to Climate Change. BioScience 2005, 55, 863. [CrossRef]

84. Voldseth, R.A.; Johnson, W.C.; Guntenspergen, G.R.; Gilmanov, T.; Millett, B.V. Adaptation of farming practices could buffer effects of climate change on Northern Prairie wetlands. Wetlands 2009, 29, 635-647. [CrossRef]

85. Rashford, B.S.; Adams, R.M.; Wu, J.; Voldseth, R.A.; Guntenspergen, G.R.; Werner, B.; Johnson, W.C. Impacts of climate change on land-use and wetland productivity in the Prairie Pothole Region of North America. Reg. Environ. Chang. 2015, 16,515-526. [CrossRef]

86. Adams, R.M.; Rosenzweig, C.; Peart, R.M.; Ritchie, J.T.; McCarl, B.A.; Glyer, J.D.; Curry, R.B.; Jones, J.W.; Boote, K.J.; Allen, L.H. Global climate change and US agriculture. Nature 1990, 345, 219-224. [CrossRef]

87. Adams, R.M.; Hurd, B.; Lenhart, S.; Leary, N. Effects of global climate change on world agriculture: An interpretive review. Clim. Res. 1998, 11, 19-30. [CrossRef]

88. Ferone, J.; DeVito, K. Shallow groundwater-surface water interactions in pond-peatland complexes along a Boreal Plains topographic gradient. J. Hydrol. 2004, 292, 75-95. [CrossRef]

89. Johnson, W.C.; Werner, B.; Guntenspergen, G.R.; Voldseth, R.A.; Millett, B.; Naugle, D.E.; Tulbure, M.G.; Carroll, R.W.; Olawsky, C.; Tracy, J. Prairie Wetland Complexes as Landscape Functional Units in a Changing Climate. BioScience 2010, 60, 128-140. [CrossRef]

90. Loesch, C.R.; Reynolds, R.E.; Hansen, L. An Assessment of Re-Directing Breeding Waterfowl Conservation Relative to Predictions of Climate Change. J. Fish Wildl. Manag. 2012, 3, 1-22. [CrossRef]

91. Bayerl, G. Geschichte der Landnutzung in der Region. Barnim-Uckermark; Berlin-Brandenburgische Akademie der Wissenschaften: Berlin, Germany, 2006; Volume 12.

92. Johnston, C.A. Wetland Losses Due to Row Crop Expansion in the Dakota Prairie Pothole Region. Wetlands 2013, 33, 175-182. [CrossRef]

93. Neyen, M. Depositional Characteristics of Glacial Kettle Holes at Kraatz and Rittgarten, NE Brandenburg, Germany. Bachelor's Thesis, University of Potsdam, Institute of Earth-and Environmental Sciences, Potsdam, Germany, 2014.

94. Stallard, R.F. Terrestrial sedimentation and the carbon cycle: Coupling weathering and erosion to carbon burial. Glob. Biogeochem. Cycles 1998, 12, 231-257. [CrossRef]

95. Vaché, K.B.; Eilers, J.M.; Santelmann, M. Water Quality Modeling of Alternative Agriculture Scenarios in the U.S. Corn Belt. JAWRA J. Am. Water Resour. Assoc. 2002, 38, 773-787. [CrossRef]

96. Riseng, C.M.; Wiley, M.J.; Black, R.W.; Munn, M.D. Impacts of agricultural land use on biological integrity: A causal analysis. Ecol. Appl. 2011, 21, 3128-3146. [CrossRef]

97. Euliss, N.H.; Mushet, D.M. Influence of agriculture on aquatic invertebrate communities of temporary wetlands in the Prairie Pothole Region of North Dakota, USA. Wetlands 1999, 19, 578-583. [CrossRef]

98. Main, A.R.; Headley, J.V.; Peru, K.M.; Michel, N.L.; Cessna, A.J.; Morrissey, C.A. Widespread Use and Frequent Detection of Neonicotinoid Insecticides in Wetlands of Canada's Prairie Pothole Region. PLoS ONE 2014, 9, e92821. [CrossRef] [PubMed]

99. Waite, D.; Sommerstad, H.; Grover, R.; Kerr, L.; Westcott, N. Pesticides in ground water, surface water and spring runoff in a small saskatchewan watershed. Environ. Toxicol. Chem. 1992, 11, 741-748. [CrossRef]

100. Henry, B.; Wesner, J.S.; Kerby, J.L. Cross-Ecosystem Effects of Agricultural Tile Drainage, Surface Runoff, and Selenium in the Prairie Pothole Region. Wetlands 2019. [CrossRef]

101. Benbow, M.E.; Merritt, R.W. Road-salt toxicity of select Michigan wetland macroinvertebrates under different testing conditions. Wetlands 2004, 24, 68-76. [CrossRef]

102. Cedergreen, N.; Streibig, J.C. The toxicity of herbicides to non-target aquatic plants and algae: Assessment of predictive factors and hazard. Pest Manag. Sci. 2005, 61, 1152-1160. [CrossRef]

103. Forson, D.; Storfer, A. Effects of Atrazine and Iridovirus Infection on Survival and Life-History Traits of the Long-Toed Salamander (Ambystoma Macrodactylum). Environ. Toxicol. Chem. 2006, 25, 168-173. [CrossRef]

104. DeLorenzo, M.E.; Scott, G.I.; Ross, P.E. Toxicity of pesticides to aquatic microorganisms: A review. Environ. Toxicol. Chem. 2001, 20, 84-98. [CrossRef]

105. Langpap, C.; Wu, J. Potential Environmental Impacts of Increased Reliance on Corn-Based Bioenergy. Environ. Resour. Econ. 2010, 49, 147-171. [CrossRef]

106. Dahl, T.E. Status and Trends of Prairie Wetlands in the United States 1997 to 2009; US Department of the Interior, Fish and Wildlife Service, Ecological Services: Washington, DC, USA, 2014. 
107. Van Meter, K.J.; Basu, N.B. Signatures of human impact: Size distributions and spatial organization of wetlands in the Prairie Pothole landscape. Ecol. Appl. 2015, 25, 451-465. [CrossRef]

108. Poiani, K.A.; Johnson, W.C.; Kittel, T.G.F. Sensitivity of a prairie wetland to increased temperature and seasonal precipitation changes. JAWRA J. Am. Water Resour. Assoc. 1995, 31, 283-294. [CrossRef]

109. Leitch, J.A. Economics of Prairie Wetland Drainage. Trans. ASAE 1983, 26, 1465-1470. [CrossRef]

110. Anderson, D.J.; Vondracek, B. Insects as indicators of land use in three ecoregions in the Prairie Pothole Region. Wetlands 1999, 19, 648-664. [CrossRef]

111. Miller, B.A.; Crumpton, W.G.; Valk, A.G. Spatial distribution of historical wetland classes on the Des Moines Lobe, Iowa. Wetlands 2009, 29, 1146-1152. [CrossRef]

112. Schilling, K.; Dinsmore, S. Monitoring the Wildlife, Hydrology and Water Quality of Drained Wetlands of the Des Moines Lobe, Northern Iowa: Introduction to Special Feature. Wetlands 2018, 38, 207-210. [CrossRef]

113. Van Der Kamp, G.; Hayashi, M. Groundwater-wetland ecosystem interaction in the semiarid glaciated plains of North America. Hydrogeol. J. 2008, 17, 203-214. [CrossRef]

114. Shaw, D.A.; Pietroniro, A.; Martz, L. Topographic analysis for the prairie pothole region of Western Canada. Hydrol. Process. 2012, 27, 3105-3114. [CrossRef]

115. Gasiorowski, M. Deposition Rate of Lake Sediments Under Different Alternative Stable States. Geochronometria 2008, 32, 29-35. [CrossRef]

116. Berthold, S.; Bentley, L.R.; Hayashi, M. Integrated hydrogeological and geophysical study of depression-focused groundwater recharge in the Canadian prairies. Water Resour. Res. 2004, 40. [CrossRef]

117. Moorhead, K.K. Effects of drought on the water-table dynamics of a southern Appalachian mountain floodplain and associated fen. Wetlands 2003, 23, 792-799. [CrossRef]

118. Johnson, W.C.; Boettcher, S.E.; Poiani, K.A.; Guntenspergen, G. Influence of weather extremes on the water levels of glaciated prairie wetlands. Wetlands 2004, 24, 385-398. [CrossRef]

119. Dempster, A.; Ellis, P.; Wright, B.; Stone, M.; Price, J. Hydrogeological evaluation of a southern Ontario kettle-hole peatland and its linkage to a regional aquifer. Wetlands 2006, 26, 49-56. [CrossRef]

120. Hayashi, M.; Van Der Kamp, G.; Rudolph, D.L. Water and solute transfer between a prairie wetland and adjacent uplands, 2. Chloride cycle. J. Hydrol. 1998, 207, 56-67. [CrossRef]

121. Euliss, N.H.; Mushet, D.M. Water-level fluctuation in wetlands as a function of landscape condition in the prairie pothole region. Wetlands 1996, 16, 587-593. [CrossRef]

122. Van Der Kamp, G.; Stolte, W.J.; Clark, R.G. Drying out of small prairie wetlands after conversion of their catchments from cultivation to permanent brome grass. Hydrol. Sci. J. 1999, 44, 387-397. [CrossRef]

123. Raatz, L.; Bacchi, N.; Pirhofer-Walzl, K.; Glemnitz, M.; Müller, M.E.H.; Joshi, J.; Scherber, C. How much do we really lose?-Yield losses in the proximity of natural landscape elements in agricultural landscapes. Ecol. Evol. 2019, 9, 7838-7848. [CrossRef]

124. Kanwar, R.S.; Baker, J.L.; Mukhtar, S. Excessive Soil Water Effects at Various Stages of Development on the Growth and Yield of Corn. Trans. ASAE 1988, 31, 0133-0141. [CrossRef]

125. Ahmad, N.; Kanwar, R.S.; Kaspar, T.C.; Bailey, T.B. Effect of Soil Surface Submergence and a Water Table on Vegetative Growth and Nutrient Uptake of Corn. Trans. ASAE 1992, 35, 1173-1177. [CrossRef]

126. McKergow, L.; Gallant, J.; Dowling, T. Modelling wetland extent using terrain indices, Lake Taupo, NZ. In Proceedings of MODSIM 2007 International Congress on Modelling and Simulation; University of Canterbury: Christchurch, New Zealand, December 2007; pp. 74-80.

127. Lischeid, G.; Kalettka, T.; Holländer, M.; Steidl, J.; Merz, C.; Dannowski, R.; Hohenbrink, T.L.; Lehr, C.; Onandia, G.; Reverey, F.; et al. Natural ponds in an agricultural landscape: External drivers, internal processes, and the role of the terrestrial-aquatic interface. Limnologica 2018, 68, 5-16. [CrossRef]

128. Engstrom, D.R.; Schottler, S.P.; Leavitt, P.R.; Havens, K.E. A reevaluation of the cultural eutrophication of Lake Okeechobee using multiproxy sediment records. Ecol. Appl. 2006, 16, 1194-1206. [CrossRef]

129. Preston, T.M.; Sojda, R.S.; Gleason, R.A. Sediment accretion rates and sediment composition in Prairie Pothole wetlands under varying land use practices, Montana, United States. J. Soil Water Conserv. 2013, 68, 199-211. [CrossRef]

130. Dieter, C.D. Water Turbidity in Tilled and Untilled Prairie Wetlands. J. Freshw. Ecol. 1991, 6, 185-189. [CrossRef] 
131. Detenbeck, N.E.; Elonen, C.M.; Taylor, D.L.; Cotter, A.M.; Puglisi, F.A.; Sanville, W.D. Effects of agricultural activities and best management practices on water quality of seasonal prairie pothole wetlands. Wetl. Ecol. Manag. 2002, 10, 335-354. [CrossRef]

132. Dreger, F. Sölle-Bedeutung für die Biodiversität in Agrarlandschaften unterschiedlicher Landschaftsräume. Beiträge Forstwirtschaft Landschaftsökol. 2002, 36, 88-92.

133. Davies, B.R.; Biggs, J.; Williams, P.; Whitfield, M.; Nicolet, P.; Sear, D.; Bray, S.; Maund, S. Comparative biodiversity of aquatic habitats in the European agricultural landscape. Agric. Ecosyst. Environ. 2008, 125, 1-8. [CrossRef]

134. Ristow, M.; Herrmann, A.; Illig, H.; Klemm, G.; Kummer, V.; Kläge, H.-C.; Machatzi, B.; Raetzel, S.; Schwarz, R.; Zimmermann, F. Liste und Rote Liste der etablierten Gefäßpflanzen Brandenburgs. Naturschutz Landschaftspflege Brandenburg 2006, 15, 70-80.

135. Lozada-Gobilard, S.; Stang, S.; Pirhofer-Walzl, K.; Kalettka, T.; Heinken, T.; Schröder, B.; Eccard, J.; Joshi, J. Environmental filtering predicts plant-community trait distribution and diversity: Kettle holes as models of meta-community systems. Ecol. Evol. 2019, 9, 1898-1910. [CrossRef]

136. Dovrat, G.; Perevolotsky, A.; Ne'Eman, G. Wild boars as seed dispersal agents of exotic plants from agricultural lands to conservation areas. J. Arid Environ. 2012, 78, 49-54. [CrossRef]

137. Soons, M.B.; Brochet, A.; Kleyheeg, E.; Green, A.J. Seed dispersal by dabbling ducks: An overlooked dispersal pathway for a broad spectrum of plant species. J. Ecol. 2016, 104, 443-455. [CrossRef]

138. Flaherty, K.L.; Rentch, J.S.; Grafton, W.N.; Anderson, J.T. Timing of white-tailed deer browsing affects wetland plant communities. Plant Ecol. 2018, 219, 313-324. [CrossRef]

139. Roeleke, M.; Johannsen, L.; Voigt, C.C. How Bats Escape the Competitive Exclusion Principle-Seasonal Shift from Intraspecific to Interspecific Competition Drives Space Use in a Bat Ensemble. Front. Ecol. Evol. 2018, 6, 101. [CrossRef]

140. Fischer, C.; Schröder, B. Predicting spatial and temporal habitat use of rodents in a highly intensive agricultural area. Agric. Ecosyst. Environ. 2014, 189, 145-153. [CrossRef]

141. Johnston, C.A.; McIntyre, N.E. Effects of cropland encroachment on prairie pothole wetlands: Numbers, density, size, shape, and structural connectivity. Landsc. Ecol. 2019, 34, 827-841. [CrossRef]

142. Thomas, S.M.; Moloney, K.A. Combining the effects of surrounding land-use and propagule pressure to predict the distribution of an invasive plant. Biol. Invasions 2014, 17, 477-495. [CrossRef]

143. Swanson, G.A.; Duebbert, H.F. Wetland habitats of waterfowl in the prairie pothole region. In Northern Prairie Wetlands; van der Valk, A.G., Ed.; Iowa State University Press: Ames, IA, USA, 1989; pp. 228-267.

144. Stoate, C.; Boatman, N.D.; Borralho, R.J.; Carvalho, C.; De Snoo, G.R.; Eden, P. Ecological impacts of arable intensification in Europe. J. Environ. Manag. 2001, 63, 337-365. [CrossRef]

145. Geiger, F.; De Snoo, G.R.; Berendse, F.; Guerrero, I.; Morales, M.B.; Oñate, J.J.; Eggers, S.; Pärt, T.; Bommarco, R.; Bengtsson, J.; et al. Landscape composition influences farm management effects on farmland birds in winter: A pan-European approach. Agric. Ecosyst. Environ. 2010, 139, 571-577. [CrossRef]

146. Barraquand, F.; Martinet, V. Biological conservation in dynamic agricultural landscapes: Effectiveness of public policies and trade-offs with agricultural production. Ecol. Econ. 2011, 70, 910-920. [CrossRef]

147. Tscharntke, T.; Clough, Y.; Wanger, T.C.; Jackson, L.; Motzke, I.; Perfecto, I.; VanderMeer, J.; Whitbread, A. Global food security, biodiversity conservation and the future of agricultural intensification. Biol. Conserv. 2012, 151, 53-59. [CrossRef]

148. Savoie, P.; Lavoie, F.; D'Amours, L.; Schroeder, W.; Kort, J. Harvesting natural willow rings with a bio-baler around Saskatchewan prairie marshes. Can. Biosyst. Eng. 2010, 52, 2.1-2.5.

149. Vickruck, J.; Best, L.R.; Gavin, M.P.; Devries, J.H.; Galpern, P. Pothole wetlands provide reservoir habitat for native bees in prairie croplands. Biol. Conserv. 2019, 232, 43-50. [CrossRef]

150. Gallai, N.; Salles, J.-M.; Settele, J.; Vaissière, B.E. Economic valuation of the vulnerability of world agriculture confronted with pollinator decline. Ecol. Econ. 2009, 68, 810-821. [CrossRef]

151. Eilers, E.J.; Kremen, C.; Greenleaf, S.S.; Garber, A.K.; Klein, A. Contribution of Pollinator-Mediated Crops to Nutrients in the Human Food Supply. PLoS ONE 2011, 6, e21363. [CrossRef] [PubMed]

152. Vanbergen, A.J.; Initiative, T.I.P. Threats to an ecosystem service: Pressures on pollinators. Front. Ecol. Environ. 2013, 11, 251-259. [CrossRef] 
153. Stanley, D.A.; Garratt, M.; Wickens, J.B.; Wickens, V.J.; Potts, S.G.; Raine, N.E. Neonicotinoid pesticide exposure impairs crop pollination services provided by bumblebees. Nature 2015, 528, 548-550. [CrossRef] [PubMed]

154. Goulson, D.; Nicholls, E.; Rotheray, E.; Botías, C. Qualifying pollinator decline evidence-Response. Science 2015, 348, 982. [CrossRef] [PubMed]

155. Giannini, T.C.; Acosta, A.L.; Garófalo, C.A.; Saraiva, A.M.; Alves-Dos-Santos, I.; Imperatriz-Fonseca, V.L. Pollination services at risk: Bee habitats will decrease owing to climate change in Brazil. Ecol. Model. 2012, 244, 127-131. [CrossRef]

156. Kerr, J.T.; Pindar, A.; Galpern, P.; Packer, L.; Potts, S.G.; Roberts, S.M.; Rasmont, P.; Schweiger, O.; Colla, S.R.; Richardson, L.L.; et al. Climate change impacts on bumblebees converge across continents. Science 2015, 349, 177-180. [CrossRef]

157. Spiesman, B.J.; Inouye, B.D. Habitat loss alters the architecture of plant-pollinator interaction networks. Ecology 2013, 94, 2688-2696. [CrossRef]

158. Fahrig, L. Effects of Habitat Fragmentation on Biodiversity. Annu. Rev. Ecol. Evol. Syst. 2003, 34, 487-515. [CrossRef]

159. Koh, I.; Lonsdorf, E.V.; Williams, N.M.; Brittain, C.; Isaacs, R.; Gibbs, J.; Ricketts, T.H. Modeling the status, trends, and impacts of wild bee abundance in the United States. Proc. Natl. Acad. Sci. USA 2015, 113, 140-145. [CrossRef]

160. Withey, P.; van Kooten, G.C. Wetlands retention and optimal management of waterfowl habitat under climate change. J. Agric. Resour. Econ. 2014, 39, 1-18.

161. Dean, W.E.; Gorham, E. Magnitude and significance of carbon burial in lakes, reservoirs, and peatlands. Geology 1998, 26, 535-538. [CrossRef]

162. Downing, J.A.; Cole, J.J.; Middelburg, J.J.; Striegl, R.G.; Duarte, C.M.; Kortelainen, P.; Prairie, Y.T.; Laube, K.A. Sediment organic carbon burial in agriculturally eutrophic impoundments over the last century. Glob. Biogeochem. Cycles 2008, 22. [CrossRef]

163. Heathcote, A.J.; Filstrup, C.; Kendall, D.; Downing, J. Biomass pyramids in lake plankton: Influence of Cyanobacteria size and abundance. Inland Waters 2016, 6, 250-257. [CrossRef]

164. Kleeberg, A.; Neyen, M.; Schkade, U.-K.; Kalettka, T.; Lischeid, G. Sediment cores from kettle holes in NE Germany reveal recent impacts of agriculture. Environ. Sci. Pollut. Res. 2015, 23, 7409-7424. [CrossRef]

165. Kazanjian, G.; Flury, S.; Attermeyer, K.; Kalettka, T.; Kleeberg, A.; Premke, K.; Köhler, J.; Hilt, S. Primary production in nutrient-rich kettle holes and consequences for nutrient and carbon cycling. Hydrobiologia 2017, 806, 77-93. [CrossRef]

166. Reverey, F.; Grossart, H.-P.; Premke, K.; Lischeid, G. Carbon and nutrient cycling in kettle hole sediments depending on hydrological dynamics: A review. Hydrobiologia 2016, 775, 1-20. [CrossRef]

167. Sahuquillo, M.; Miracle, M.R.; Morata, S.M.; Vicente, E. Nutrient dynamics in water and sediment of Mediterranean ponds across a wide hydroperiod gradient. Limnologica 2012, 42, 282-290. [CrossRef]

168. Phillips, R.L.; Beeri, O. The role of hydropedologic vegetation zones in greenhouse gas emissions for agricultural wetland landscapes. Catena 2008, 72, 386-394. [CrossRef]

169. Gleason, R.A.; Tangen, B.A.; Browne, B.A.; Euliss, N.H., Jr. Greenhouse gas flux from cropland and restored wetlands in the Prairie Pothole Region. Soil Biol. Biochem. 2009, 41, 2501-2507. [CrossRef]

170. Pennock, D.; Yates, T.; Bedard-Haughn, A.; Phipps, K.; E Farrell, R.; McDougal, R. Landscape controls on $\mathrm{N} 2 \mathrm{O}$ and $\mathrm{CH} 4$ emissions from freshwater mineral soil wetlands of the Canadian Prairie Pothole region. Geoderma 2010, 155, 308-319. [CrossRef]

171. Tangen, B.A.; Finocchiaro, R.; Gleason, R.A. Effects of land use on greenhouse gas fluxes and soil properties of wetland catchments in the Prairie Pothole Region of North America. Sci. Total. Environ. 2015, 533, 391-409. [CrossRef]

172. Cole, J.J.; Prairie, Y.T.; Caraco, N.F.; McDowell, W.H.; Tranvik, L.J.; Striegl, R.G.; Duarte, C.M.; Kortelainen, P.; Downing, J.A.; Middelburg, J.J.; et al. Plumbing the Global Carbon Cycle: Integrating Inland Waters into the Terrestrial Carbon Budget. Ecosystems 2007, 10, 172-185. [CrossRef]

173. Battin, T.J.; Luyssaert, S.; Kaplan, L.A.; Aufdenkampe, A.K.; Richter, A.; Tranvik, L.J. The boundless carbon cycle. Nat. Geosci. 2009, 2, 598-600. [CrossRef] 
174. Raymond, P.A.; Hartmann, J.; Lauerwald, R.; Sobek, S.; McDonald, C.P.; Hoover, M.; Butman, D.; Striegl, R.; Mayorga, E.; Humborg, C.; et al. Global carbon dioxide emissions from inland waters. Nature 2013, 503, 355-359. [CrossRef]

175. Lipp, T. Kettle Holes and Landscape Planning Consideration of a typical landscape element in the Federal States of Brandenburg and Mecklenburg-Vorpommern. Naturschutz Landschaftsplanung 2006, 38, 287.

176. Müller, M.; Koszinski, S.; Bangs, D.E.; Wehrhan, M.; Ulrich, A.; Verch, G.; Brenning, A. Crop biomass and humidity related factors reflect the spatial distribution of phytopathogenic Fusarium fungi and their mycotoxins in heterogeneous fields and landscapes. Precis. Agric. 2016, 17, 698-720. [CrossRef]

177. Cottet, M.; Piegay, H.; Bornette, G. Does human perception of wetland aesthetics and healthiness relate to ecological functioning? J. Environ. Manag. 2013, 128, 1012-1022. [CrossRef]

178. Gregory, K.; Davis, R. The Perception of Riverscape Aesthetics: An Example from Two Hampshire Rivers. J. Environ. Manag. 1993, 39, 171-185. [CrossRef]

179. House, M.A.; Sangster, E.K. Public Perception of River-Corridor Management. Water Environ. J. 1991, 5, 312-316. [CrossRef]

180. Berger, G.; Pfeffer, H.; Kächele, H.; Andreas, S.; Hoffmann, J. Nature protection in agricultural landscapes by setting aside unproductive areas and ecotones within arable fields ("Infield Nature Protection Spots"). J. Nat. Conserv. 2003, 11, 221-233. [CrossRef]

181. Westendorff, M.; Kalettka, T.; Jueg, U. Occurrence of leeches (Hirudinea) in different types of water bodies in northeast Germany (Brandenburg). Lauterbornia 2008, 65, 153-162.

182. Pankratz, R. A Review of Wetland Policy and Practice: Towards a Strategy for the Development of a Wetland Policy for Manitoba. Master's Thesis, University of Manitoba, Winnipeg, MB, Canada, 2010.

183. MLUL. Erlass des Ministeriums für Ländliche Entwicklung, Umwelt und Landwirtschaft zur Bewirtschaftung eines Teiles des Gebietes von gemeinschaftlicher Bedeutung "Schwemmpfuhl” vom 22. März 2016 (ABl. 16, [Nr. 16], p. 431). Available online: http://bit.ly/2GCUbEB (accessed on 2 September 2020).

184. MLUL. Erlass des Ministeriums für Ländliche Entwicklung, Umwelt und Landwirtschaft zur Bewirtschaftung von Teilbereichen der Gebiete von gemeinschaftlicher Bedeutung "Müncheberg” und "Müncheberg Ergänzung" mit der Bezeichnung "Sölle südlich Müncheberg” vom 18. August 2017 (ABl./17, [Nr. 37], p. 815). Available online: http://bit.ly/36KJ9HU (accessed on 2 September 2020).

185. Wachenheim, C.; Lim, S.H.; Roberts, D.C.; Devney, J. Landowner valuation of a working wetlands program in the Prairie Pothole Region. Agric. Econ. 2019, 50, 465-478. [CrossRef]

186. Tittonell, P. Ecological intensification of agriculture-sustainable by nature. Curr. Opin. Environ. Sustain. 2014, 8, 53-61. [CrossRef]

187. Frielinghaus, M.; Vahrson, W.-G. Soil translocation by water erosion from agricultural cropland into wet depressions (morainic kettle holes). Soil Tillage Res. 1998, 46, 23-30. [CrossRef] 